Al Maal : Journal of Islamic Economics and Banking

http://jurnal.umt.ac.id/index.php/jieb

E-ISSN : $\quad 2580-3816$

Vol : 3 No. 1 Bulan Juli Tahun 2021

Hlm : $1-11$

DOI : $\quad$ : 10.31000/almaal.v3i1.4614

\title{
Pengaruh Motivasi Dan Pengetahuan Terhadap Minat Berinvestasi Saham Di Pasar Modal Syariah
}

\author{
Sabik Khumaini ${ }^{*}$, Ayunda Jinan Nadiya ${ }^{2}$ \\ 1,2, Prodi Perbankan Syariah, Fakultas Agama Islam, Universitas Muhammadiyah Tangerang, \\ Indonesia \\ *sabik81@gmail.com
}

\section{ABSTRACT}

This study aimed to determine the influenced of motivation and knowledge of students the study program Islamic banking on invest interest stock in the Islamic Capital Market. The sample in this research is 67 students. The test of the instrument was analyzed by using validity test and reliability test. The analysis technique used in this study is the descriptive statistics, classic assumption test and multiple linear regression. The classical assumption test consists of, normality test, multicollinearity test, heteroscedasticity test and autocorrelation test. Hypothesis test use the determination test, $F$ test, and t test. The results showed that, motivation partially has an insignificant positive influence on invest interest stock in the Islamic Capital Market. Knowledge partially had a significant positive influence on invest interest stock in the Islamic Capital Market. Meanwhile, simultaneously based on the results of the F statistical test, the independent variables of motivation and knowledge together have a significant and positive influence on the dependent variable invest interest stock. The predictive ability of these two variables on invest interest stocks is $46.0 \%$, while the remaining $54.0 \%$ is influenced by other variables outside the regression model.

Keywords: Motivation; Knowledge; Invest Interest Stock.

\begin{abstract}
ABSTRAK
Penelitian ini bertujuan untuk mengetahui pengaruh motivasi dan pengetahuan mahasiswa program studi perbankan syariah terhadap minat berinvestasi saham di Pasar Modal Syariah. Sampel dalam penelitian ini adalah sebanyak 67 Mahasiswa/i. Uji coba instrumen dianalisis dengan menggunakan uji validitas dan uji reliabilitas. Teknik analisis yang digunakan dalam penelitian ini adalah statistik deskriptif, uji asumsi klasik, dan regresi linear berganda. Uji asumsi klasik terdiri dari, uji normalitas, uji multikolinearitas, uji heterokedastisitas, dan uji autokorelasi. Uji hipotesis menggunakan uji determinasi, uji $F$, dan uji t. Hasil penelitian menunjukkan bahwa, motivasi secara parsial berpengaruh positif dan tidak signifikan terhadap minat berinvestasi saham di Pasar Modal Syariah. Pengetahuan secara parsial berpengaruh positif dan signifikan terhadap minat berinvestasi saham di Pasar Modal Syariah. Sedangkan secara simultan berdasarkan hasil uji statistik $F$, variabel independen motivasi dan pengetahuan secara bersama-sama berpengaruh positif dan signifikan terhadap variabel dependen minat berinvestasi saham. Kemampuan prediksi dari kedua variabel tersebut terhadap minat berinvestasi saham sebesar 46,0\%, sedangkan sisanya 54,0\% dipengaruhi oleh variabel lain di luar model regresi.
\end{abstract}

Kata kunci : Motivasi; Pengetahuan; Minat Berinvestasi Saham. 


\section{Pendahuluan}

Seiring perkembangan teknologi dan perekonomian saat ini, masyarakat tidak asing lagi dengan namanya investasi. Investasi pada dasarnya adalah kolaborasi antara berbagai pihak untuk melakukan kerjasama yang saling menguntungkan. Investasi adalah aktivitas penanaman modal pada salah satu atau beberapa instrumen pada waktu tertentu dengan mengharapkan imbal hasil (Auliya, 2019). Maka dari itu, pasar modal syariah bersama perusahaan sekuritas berusaha untuk memberikan motivasi dan pengetahuan berinvestasi saham di pasar modal syariah. Upaya tersebut diharapkan dapat membuat masyarakat memiliki pengetahuan lebih tentang investasi saham yang baik sesuai syariah, terhindar dari berbagai praktik investasi yang tidak rasional, penipuan, dan dapat menumbuhkan minat berinvestasi saham di masyarakat salah satunya mahasiswa.

Motivasi dan pengetahuan berinvestasi saham yang telah diberikan yaitu melalui media sosial, seminar, dan sekolah pasar modal syariah (SPMS). Dalam SPMS tersebut memaparkan tentang berinvestasi saham dengan harga saham di Bursa Efek Indonesia sangat bervariasi. Apalagi tujuan dari adanya pasar modal syariah yaitu agar masyarakat turut serta dalam bisnis dan perekonomian di Indonesia. Dengan demikian, dapat membuat masyarakat salah satunya mahasiswa berinvestasi saham yang mayoritas uang sakunya diperoleh dari orang tua.

Pada April 2019 kepemilikan efek lokal mengalami kenaikan dari 51,77\% di tahun 2016 menjadi 54,25\% di akhir April 2019 dan pada kepemilikan efek asing mengalami penurunan dari 48,23\% di tahun 2016 menjadi 45,75\% diakhir April tahun 2019 (KSEI, 2019). Apalagi jumlah saham syariah dalam daftar efek syariah meningkat dari tahun 2016 berjumlah 345, di tahun 2019 menjadi 445. Dengan adanya kenaikan kepemilikan lokal dan jumlah efek yang tersimpan tersebut membuat masyarakat khususnya mahasiswa untuk lebih termotivasi terhadap minat berinvestasi di pasar modal syariah agar turut serta sebagai bagian yang berperan atas kepemilikan efek salah satunya saham di Indonesia.

Pasar Modal Syariah juga terdapat Fatwa Dewan Syariah Nasional nomor 40/DSN-MUI/X/2003 tentang pasar modal, sebagai pedoman umum penerapan prinsip syariah dibidang pasar modal. Dalam Fatwa Dewan Syariah Nasional No. 40 tahun 2003 disebutkan, pasar modal syariah adalah kegiatan yang berkaitan dengan perdagangan efek syariah perusahaan Public yang berhubungan dengan efek yang diterbitkannya dan lembaga profesi terkait, dimana semua produk dan mekanisme opersionalnya berjalan tidak bertentangan dengan hukum muamalat Islamiyah (Said, 2019).

Dengan berinvetasi saham, mahasiswa akan dapat mengasah tanggung jawab dalam mengelola sahamnya, menambah peluang penghasilan yang dapat dijadikan tabungan bagi mahasiswa untuk masa yang akan datang, dan dapat mencapai kondisi dimana bebas secara finansial dalam mencukupi segala kebutuhan. Untuk memperoleh hal tersebut, mahasiswa harus terus memantau kenaikan dan penurun saham yang diinvestasikan. Dalam berinvestasi, keuntungan terbagi menjadi 2 yaitu Capital Gain dan Cashflow. Capital Gain adalah keuntungan yang didapat satu kali saja, yaitu dari hasil penjualan instrumen investasi. Sedangkan, Cashflow adalah keuntungan yang didapatkan secara berkala, dapat disebut dengan dividen (Mumpuni dan Darmawan, 2017).

Malik (2017) dalam penelitiannya yang berjudul Analisis Faktor-Faktor yang Mempengaruhi Minat Masyarakat Berinvestasi di Pasar Modal Syariah Melalui Bursa Galeri Investasi UISI. Hasil penelitian ini menunjukan bahwa faktor-faktor yang 
mempengaruhi minat investor melalui bursa galeri investasi UISI salah satunya adalah faktor motivasi dalam berinvestasi di pasar modal syariah.

Pajar (2017) dalam penelitiannya yang berjudul Pengaruh Motivasi Investasi Dan Pengetahuan Investasi Terhadap Minat Investasi Di Pasar Modal Pada Mahasiswa FE UNY. Hasil penelitian ini menunjukan bahwa motivasi dan pengetahuan investasi terhadap minat investasi di pasar modal pada mahasiswa FE Universitas Negeri Yogyakarta berpengaruh dan signifikan.

\section{KAJIAN LITERATUR}

Motivasi berasal dari bahasa latin "Movere" yang berarti dorongan, daya penggerak atau kekuatan yang menyebabkan suatu tindakan atau perbuatan (Priansa, 2017). Motivasi investasi adalah dorongan pada diri seseorang untuk melakukan suatu tindakan yang berkaitan dengan investasi (Cahya dan Kusuma, 2019). Maka, dapat disimpulkan motivasi berinvestasi adalah segala sesuatu yang mendorong seseorang untuk bertindak dalam melakukan penanaman modal. Dalam motivasi, terdapat 3 teori motivasi diantaranya yaitu motivasi untuk berprestasi, motivasi untuk berkuasa, dan motivasi untuk bersahabat. Pengukuran motivasi di sini maksudnya adalah yang berhubungan dengan efektivitas motivasi dalam mempengaruhi sikap dan tingkah laku manusia (Maunah, 2014).

Pengetahuan adalah Informasi yang diinterprestasikan oleh seseorang dengan meengunakan sejarah, pengalaman, dan skema interprestasi yang dimilikinya (Indarti, 2014). Pengetahuan investasi adalah informasi yang telah diproses tentang komitmen mengalokasikan sumber daya untuk memperoleh keuntungan di masa mendatang sebagai imbalan atas waktu dan risiko terkait investasi tersebut (Mulyana, 2019). Pengetahuan berinvestasi berupa pengetahuan tentang tujuan berinvestasi saham syariah, keuntungan investasi saham syariah, risiko berinvestasi saham, instrumen investasi, memilih saham syariah serta memiliki pengetahuan investasi yang aman. Keamanan investasi pasar modal biasanya dipantau dan diawasi oleh OJK. Dan di dalam pasar modal syariah di lengkapi dengan Dewan Pengawas Syariah serta adanya Fatwa MUI.

Minat merupakan bentuk sikap seseorang berupa rasa lebih suka dan rasa keterikatan terhadap suatu hal atau aktivitas tanpa ada yang menyuruh (Situmorang, 2014). Minat investasi dapat disimpulkan bahwa suatu ketertarikan yang kuat untuk menanamkan modal guna mendapatkan keuntungan di masa yang akan datang (Darmawan, 2019). Memiliki minat berinvestasi akan berusaha meluangkan waktu untuk mempelajari lebih jauh tentang investasi atau akan langsung mencoba berinvestasi bahkan menambah porsi investasinya. Hal lain juga seperti melihat video tentang cara berinvestasi saham di pasar modal syariah.

Saham merupakan bukti kepemilikan dari suatu perusahaan. Membeli saham berarti memiliki sebagian dari perusahaan. Saham Syariah merupakan surat berharga bukti penyertaan modal pada suatu perusahaan dan dengan bukti penyertaan tersebut pemegang saham berhak untuk mendapatkan bagian hasil dari usaha perusahaan tersebut. Konsep penyertaan modal dengan hak bagi hasil usaha ini merupakan konsep yang tidak bertentangan dengan prinsip syariah.

Pasar modal syariah dapat diartikan sebagai kegiatan dalam pasar modal yang diatur dalam UUPM yang tidak bertentangan dengan prinsip syariah. Oleh karena itu, 
pasar modal syariah bukan suatu sistem yang terpisah dari sistem pasar modal secara keseluruhan. Terdapat beberapa karakteristik khusus pasar modal syariah yaitu bahwa produk dan mekanisme transaksi tidak bertentangan dengan prinsip syariah (Nandar, 2018). Sejarah pasar modal syariah di Indonesia dimulai dari diterbitkannya Reksa Dana Syariah oleh PT. Danareksa Investment Management pada 3 Juli 1997, dan akhirnya pada tahun 2016 BEI memperoleh penghargaan The Best Supporting Institution of The Year 2016 dari Global Islamic Finance Award sebagai perusahaan yang sangat aktif mendorong perkembangan pasar modal syariah Indonesia (Abdalloh, 2018). Dengan Visi dan Misi yaitu (visi) Menjadi pasar modal syariah yang memberikan kontribusi signifikan bagi peningkatan sosial, berkeadilan, dan menjamin kepentingan masyarakat, dan misinya yaitu menjadikan pasar modal syariah sebagai sarana pembiayaan bagi pemerintah dan sektor, mewujudkan pasar modal syariah yang tumbuh, stabil, berkelanjutan, dan akuntabel, dan mewujudkan sumber daya investasi pilihan masyarakat, manusia di pasar modal syariah yang berkualitas dan amanah. Dasar operasional pasar modal syariah mengacu juga kepada sejumlah regulasi yang ditetapkan pihak yang memiliki otoritas, seperti Otoritas Jasa Keuangan (OJK) dan Dewan Syariah Nasional (DSN) Majelis Ulama Indonesia (MUI) (Said, 2019). Terdapat juga beberapa produk di pasar modal syariah seperti saham syariah, reksadana syariah (Reksadana syariah menggunakan sistem wakalah) (Huda dan Nasution, 2014), Exchange Traded Fund syariah, dana investasi real estat syariah, dan obligasi syariah.

\section{Metode Penelitian Sumber Data Penelitian}

Penelitian ini dilakukan di Fakultas Agama Islam, Universitas Muhammadiyah Tangerang dengan responden mahasiswa/i program studi perbankan syariah. Penelitian ini menggunakan data primer berupa kuesioner yang disebarkan secara online melalui Google From. Kemudian, linknya dibagikan menggunakan aplikasi Whatsapp. Sampel yang diambil sebanyak 67 sampel dari 200 populasi mahasiswa/i perbankan syariah menggunakan teknik simple random sampling dengan rumus solvin yang derajat ketelitian atau nilai kritis sebesar 0,1 atau $10 \%$. Dalam teknik pengumpulan data, nilai setiap pernyataan menggunakan skala likert.

\section{Metode Analisis Data}

Penelitian ini melakukan uji coba instrumen dengan menggunakan uji validitas dan uji reliabilitas. Teknik analisis data yang digunakan adalah statistika deskriptif, uji asumsi klasik dan regresi linear berganda. Uji asumsi klasik terdiri dari uji normalitas, uji multikolinearitas, uji heterokedastisitas, dan uji auto korelasi. Selain itu juga, melakukan uji hipotesis menggunakan uji determinasi, uji F, dan uji t.

\section{Hasil dan Pembahasan Validitas}

Validitas adalah istilah yang menggambarkan kemampuan sebuah instrumen untuk mengukur apa yang ingin diukur. Maka validitas berarti membicarakan kesahihan sebuah alat ukur untuk mendapatkan data (Syahrum dan Salim, 2014). Pada penelitian ini menggunakan rumus korelasi Product Moment. Sehingga, diperoleh hasil pengujian validitas dapat ditunjukan pada tabel, sebagai berikut: 
Tabel 1 Hasil Validitas

\begin{tabular}{|c|c|c|c|c|}
\hline No & Pernyataan & $R_{x y}$ & $R_{\text {tabel }}(d f=N-2)$ & Keterangan \\
\hline \multirow[t]{6}{*}{1 . } & Motivasi: & & & \\
\hline & 1. Pernyataan 1 & 0,398 & 0,2404 & Valid \\
\hline & 2. Pernyataan 2 & 0,415 & 0,2404 & Valid \\
\hline & 3. Pernyataan 3 & 0,789 & 0,2404 & Valid \\
\hline & 4. Pernyataan 4 & 0,698 & 0,2404 & Valid \\
\hline & 5. Pernyataan 5 & 0,726 & 0,2404 & Valid \\
\hline \multirow[t]{6}{*}{2.} & Pengetahuan: & & & \\
\hline & 1. Pernyataan 1 & 0,701 & 0,2404 & Valid \\
\hline & 2. Pernyataan 2 & 0,446 & 0,2404 & Valid \\
\hline & 3. Pernyataan 3 & 0,573 & 0,2404 & Valid \\
\hline & 4. Pernyataan 4 & 0,707 & 0,2404 & Valid \\
\hline & 5. Pernyataan 5 & 0,723 & 0,2404 & Valid \\
\hline \multirow[t]{6}{*}{3.} & Minat Berinvestasi Saham: & & & \\
\hline & 1. Pernyataan 1 & 0,807 & 0,2404 & Valid \\
\hline & 2. Pernyataan 2 & 0,788 & 0,2404 & Valid \\
\hline & 3. Pernyataan 3 & 0,803 & 0,2404 & Valid \\
\hline & 4. Pernyataan 4 & 0,765 & 0,2404 & Valid \\
\hline & 5. Pernyataan 5 & 0,756 & 0,2404 & Valid \\
\hline
\end{tabular}

Berdasarkan dari tabel di atas, menunjukan bahwa setiap pernyataan pada variabel independen maupun dependen dinyatakan valid dikarenakan melebihi nilai $\mathrm{R}_{\text {tabel. }}$ Maka dapat disimpulkan, tidak ada satupun pernyataan yang tidak valid.

\section{Reabilitas}

Reabilitas adalah indek yang menunjukkan sejauh mana suatu alat dapat dipercaya, atau diandalkan (Neolaka, 2016). Pada penelitian ini menggunakan koefisien Alpha (á) dari teknik Cronbach. Maka, diperoleh hasil pengujian reabilitas pada variabel motivasi sebesar 0,611, variabel pengetahuan sebesar 0,614, dan variabel minat berinvestasi saham sebesar 0,842 . Sehingga dapat disimpulkan bahwa pernyataan pada setiap variabel yaitu realiabel. Dengan demikian, masing-masing variabel layak digunakan sebagai alat ukur serta terpercaya dalam penelitian ini.

\section{Statistik Deskriptif}

Statistik deskriptif adalah statistik yang digunakan untuk menganalisis data dengan cara mendeskripsikan atau menggambarkan data yang telah terkumpul sebagaiamana adanya tanpa bermaksud membuat kesimpulan yang berlaku untuk umum atau generalisasi (Siyoto dan Sodik, 2015). Sehingga, diperoleh hasil pengujian statistik deskriptif dapat ditunjukan pada tabel, sebagai berikut:

Tabel 2 Hasil Statistik Deskriptif

\begin{tabular}{|c|c|c|c|c|c|c|}
\hline \multicolumn{7}{|c|}{ Descriptive Statistics } \\
\hline & $N$ & Minimum & Махітит & Sum & Mean & Std. Deviation \\
\hline Motivasi & 67 & 9 & 25 & 1290 & 19,25 & 3,135 \\
\hline $\begin{array}{l}\text { Pengetahuan } \\
\text { Minat }\end{array}$ & 67 & 12 & 25 & 1332 & 19,88 & 2,371 \\
\hline $\begin{array}{l}\text { Berinvestasi } \\
\text { Saham }\end{array}$ & 67 & 5 & 25 & 1299 & 19,39 & 3,555 \\
\hline
\end{tabular}

Sumber: Data yang diolah menggunakan SPSS 24 
Berdasarkan tabel di atas, menunjukan hasil perhitungan pada variabel motivasi rata-rata (Mean) sebesar 19,25 dengan standar deviasi sebesar 3,135 hasil tersebut menunjukan nilai standar deviasi lebih kecil dibanding rata-rata motivasi yang dapat diartikan bahwa data variabel motivasi mengindikasikan hasil yang baik. Nilai terendah variabel motivasi sebesar 9 dan nilai tertinggi sebesar 25 .

Pada variabel pengetahuan rata-rata (Mean) sebesar 19,88 dengan standar deviasi sebesar 2,371 hasil tersebut menunjukan nilai standar deviasi lebih kecil dibanding ratarata pengetahuan yang dapat diartikan bahwa data variabel pengetahuan mengindikasikan hasil yang baik. Nilai terendah variabel pengetahuan sebesar 12 dan nilai tertinggi sebesar 25 .

Pada variabel minat berinvestasi saham rata-rata (Mean) sebesar 19,39 dengan standar deviasi sebesar 3,555 hasil tersebut menunjukan nilai standar deviasi lebih kecil dibanding rata-rata minat berinvestasi saham yang dapat diartikan bahwa data variabel minat berinvestasi saham mengindikasikan hasil yang baik. Nilai terendah variabel minat berinvestasi saham sebesar 5 dan nilai tertinggi sebesar 25 .

\section{Uji Asumsi Klasik}

Uji Normalitas

Uji normalitas dilakukan untuk mengetahui apakah variabel dependen, independen atau keduanya berdistribusi normal, mendekati normal atau tidak (Ariawaty dan Evita, 2018). pada uji normalitas ini menggunakan metode kolmogorov-smirnov. Sehingga, diperoleh hasil pengujian normalitas dapat ditunjukan pada tabel, sebagai berikut:

Tabel 3 Hasil Uji Normalitas

\begin{tabular}{|c|c|c|}
\hline \multicolumn{3}{|c|}{ One-Sample Kolmogorov-Smirnov Test } \\
\hline$N$ & & $\begin{array}{l}\text { Unstandardized } \\
\text { Residual } \\
67\end{array}$ \\
\hline Normal Parameters ${ }^{a, b}$ & $\begin{array}{l}\text { Mean } \\
\text { Std. } \\
\text { Deviation }\end{array}$ & $\begin{array}{l}.0000000 \\
2.57309836\end{array}$ \\
\hline $\begin{array}{l}\text { Most } \quad \text { Extreme } \\
\text { Differences }\end{array}$ & $\begin{array}{l}\text { Absolute } \\
\text { Positive } \\
\text { Negative }\end{array}$ & $\begin{array}{l}.102 \\
.097 \\
-.102\end{array}$ \\
\hline $\begin{array}{l}\text { Test Statistic } \\
\text { Asymp. Sig. (2-tailed) } \\
\text { a. Test distribution is Normal } \\
\text { b. Calculated from data. } \\
\text { c. Lilliefors Significance Cor }\end{array}$ & rection. & $\begin{array}{l}.102 \\
.083^{c}\end{array}$ \\
\hline
\end{tabular}

Sumber: Data yang diolah menggunakan SPSS 24

Berdasarkan hasil dari tabel di atas, menunjukan nilai kolmogorov-smirnov sebesar 0,102 > 0,05 dan nilai Asymp.sig sebesar 0,083>0,05 hasil tersebut sehingga data penelitian dengan jumlah sampel 67 telah memiliki data berdistribusi normal dan telah memenuhi normalitas data.

Uji Multikolineritas

Uji multikolinearitas dilakukan bertujuan untuk mendeteksi apakah variabel independen pada model regresi saling berkorelasi. kriteria keputusan tertentu yaitu 
Apabila tolerance value $>0.1$ dan $\mathrm{VIF}<10$, maka dapat ditarik kesimpulkan tidak terjadi gejala multikolinearitas antar variabel independen pada model regresi. Dan Apabila tolerance value $<0.1$ dan VIF $>10$, maka dapat disimpulkan terjadi gejala multikolinearitas antar variabel independent pada model regresi (Ariawaty dan Evita, 2018). Sehingga, diperoleh hasil pengujian multikolineritas dapat ditunjukan pada tabel, sebagai berikut:

\begin{tabular}{|c|c|c|c|}
\hline \multicolumn{4}{|c|}{ Coefficientsa } \\
\hline \multirow[t]{2}{*}{ Model } & & \multicolumn{2}{|c|}{ Collinearity Statistics } \\
\hline & & Tolerance & $V I F$ \\
\hline \multirow[t]{3}{*}{1} & (Constant) & & \\
\hline & Motivasi & .943 & 1.060 \\
\hline & Pengetahuan & .943 & 1.060 \\
\hline \multicolumn{4}{|c|}{ a. Dependent Variable: Minat Berinvestasi Saham } \\
\hline
\end{tabular}

Sumber: Data yang diolah menggunakan SPSS 24

Berdasarkan tabel di atas, hasil uji multikolinieritas maka diperoleh nilai VIF adalah sebagai berikut pada tolerance value 0,943 > 0,1 dan VIF 1,060 < 10,00. maka dapat disimpulkan tidak terjadi gejala multikolinearitas antar variabel independen dan data penelitian yang baik adalah data penelitian yang tidak terjadi multikolinieritas.

Uji Heteroskedastisitas

Uji heteroskedastisitas dilaksanakan untuk mengetahui apakah dalam sebuah model regresi terjadi ketidaksamaan varians dari residual suatu pengamatan ke pengamatan lain. Model regresi yang baik adalah tidak terjadi heteroskedastisitas (Umar, 2014). Dalam penelitian ini, uji heteroskedastisitas menggunakan metode rank spearman. Sehingga, diperoleh hasil pengujian heteroskedastisitas dapat ditunjukan pada tabel, sebagai berikut:

Tabel 5 Hasil Uji Heteroskedastisitas

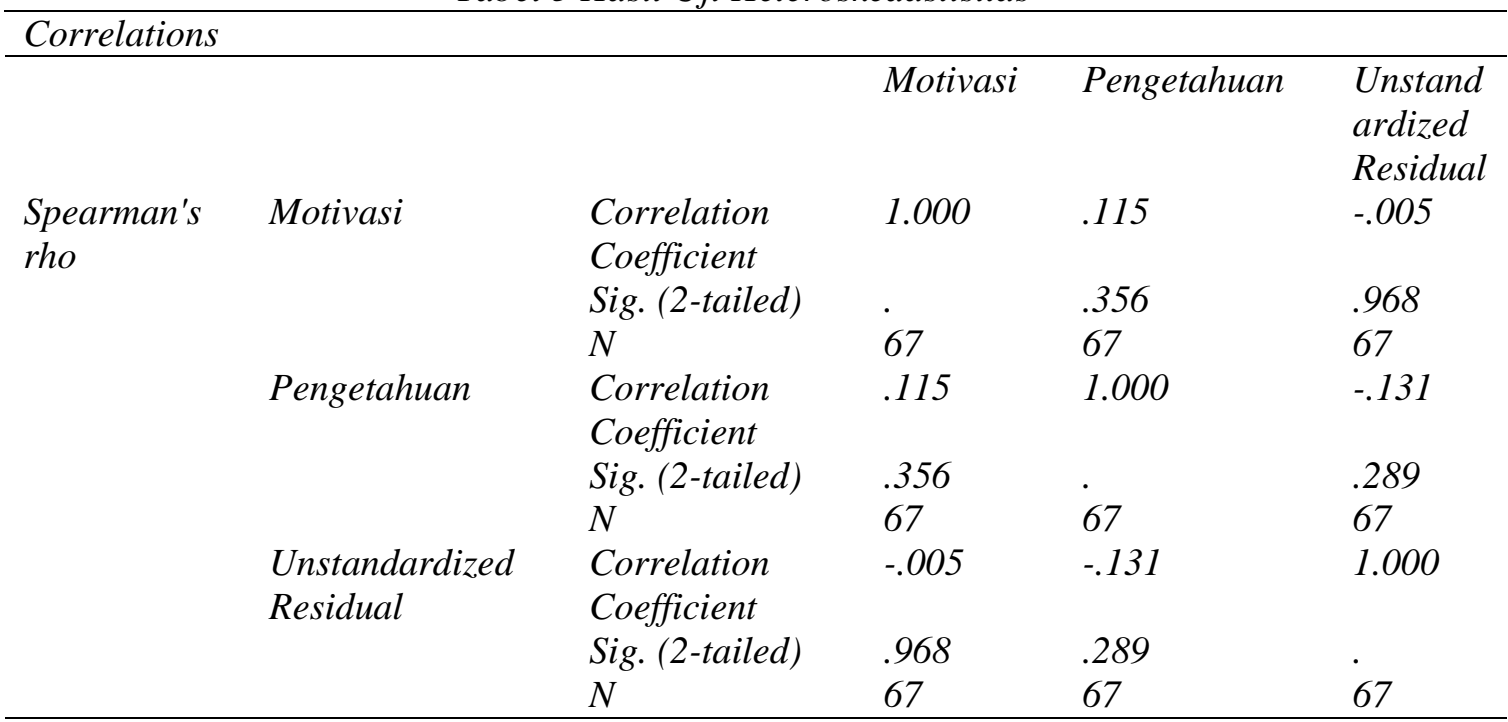

Sumber: Data yang diolah menggunakan SPSS 24

Berdasarkan uji hetorokedastisitas pada tabel di atas, dengan menggunakan metode $\mathrm{r}$ bank spearman menunjukan nilai signifikan variabel motivasi sebesar 0,968 > 0,05 dan nilai signifikan variabel pengetahuan sebesar 0,289>0,05 sehingga dapat disimpulkan tidak terjadi masalah heteroskedastisitas. 


\section{Uji Autokolerasi}

Auto korelasi ialah korelasi antara sesama urutan pengamatan dari waktu ke waktu. Untuk memeriksa adanya auto korelasi, memakai uji runs test. Uji auto korelasi dilakukan untuk mengetahui apakah dalam sebuah model regresi linier terdapat hubungan yang kuat baik positif maupun negative antar data yang ada pada variabel-variabel penelitian (Umar, 2014). Sehingga, diperoleh hasil pengujian auto korelasi dapat ditunjukan pada tabel, sebagai berikut:

Tabel 6 Hasil Uji Auto Kolerasi

\begin{tabular}{ll}
\hline Runs Test & \\
\hline & $\begin{array}{l}\text { Unstandardized } \\
\text { Residual }\end{array}$ \\
Test Value & .36083 \\
Cases $<$ Test Value & 33 \\
Cases $>=$ Test Value & 34 \\
Total Cases & 67 \\
Number of Runs & 38 \\
Z & .864 \\
Asymp. Sig. (2-tailed) & .388 \\
a. Median & \\
\hline Sumber: Data yang diolah menggunakan SPSS 24
\end{tabular}

Berdasarkan pada tabel di atas, menunjukan bahwa hasil uji auto korelasi dengan menggunakan runs test yaitu 0,388 >0,05. Dengan demikian, hasil tersebut bahwa data penelitian tidak terjadi masalah auto korelasi.

Koefisien Determinasi $\left(\mathrm{R}^{2}\right)$

Koefisien determinasi adalah kadar kontribusi variabel bebas terhadap variabel terikat. Nilai ini menyatakan proporsi variasi keseluruhan dalam nilai variabel dependen yang dapat diterangkan atau diakibatkan oleh hubungan linier dengan nilai variabel independen (Neolaka, 2016). Nilai koefisien determinasi dapat diperoleh dari nilai adjusted $\mathrm{R}^{2}$ Square, sebagai berikut:

Tabel 7 Hasil Uji Koefisien Determinasi

\begin{tabular}{lllll}
\hline \multicolumn{3}{l}{ Model Summary } \\
\hline Model & $R$ & R Square & Adjusted R Square & $\begin{array}{l}\text { Std. Error of the } \\
\text { Estimate }\end{array}$ \\
1 & $.690^{a}$ & .476 & .460 & 2.613 \\
a. Predictors: (Constant), Pengetahuan, Motivasi & \\
b. Dependent Variable: Minat Berinvestasi Saham \\
\hline \multicolumn{5}{r}{ Sumber: Data yang diolah menggunakan SPSS 24}
\end{tabular}

Berdasarkan pada tabel di atas, diperoleh koefisien determinasi Adjusted R Square sebesar 0,460 dapat disimpulkan bahwa pengaruh variabel bebas motivasi dan pengetahuan sebesar $46,0 \%$, sedangkan sisanya 54,0\% dipengaruhi oleh variabel-variabel lain di luar model regresi.

Uji F

Uji F dilakukan untuk menunjukan apakah semua variabel independen atau bebas yang dimaksudkan dalam model mempunyai pengaruh secara bersama-sama terhadap variabel dependen atau variabel terikat. Dimana $\mathrm{F}$ hitung $>\mathrm{F}$ tabel, maka $\mathrm{H}_{1}$ diterima atau secara bersama-sama variabel bebas dapat menerangkan variabel terikatnya secara 
bersamaan. Sebaliknya apabila $\mathrm{F}$ hitung $<\mathrm{F}$ tabel maka $\mathrm{H}_{0}$ diterima atau secara bersamasama variabel bebas tidak memiliki pengaruh terhadap variabel terikat. Untuk mengetahui signifikan atau tidak pengaruh secara bersama-sama variabel bebas terhadap variabel terikat maka digunakan probability sebesar 5\% $(a=0.05)$ (Sarwono, 2012). Sehingga, diperoleh hasil uji $\mathrm{F}$ dapat ditunjukan pada tabel, sebagai berikut:

Tabel 8 Hasil Uji F

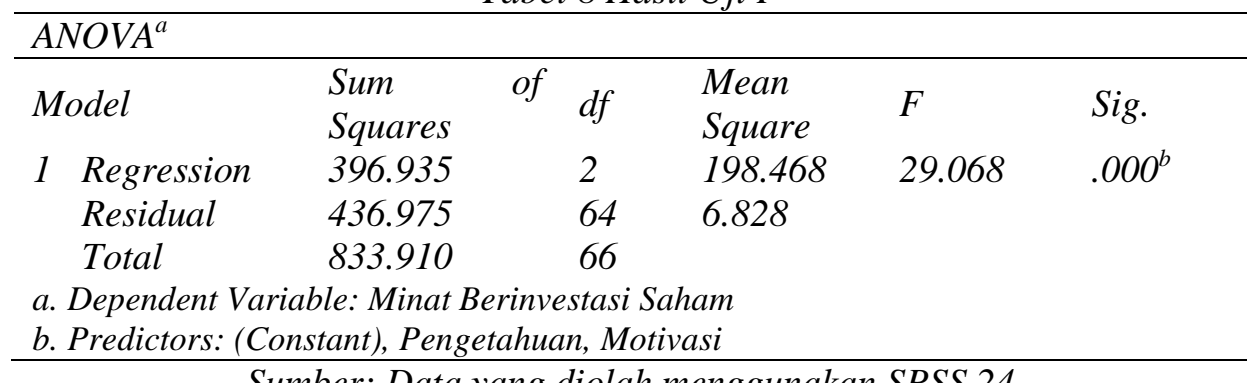

Sumber: Data yang diolah menggunakan SPSS 24

Berdasarkan pada tabel di atas, hasil uji $\mathrm{F}$ pada tabel 4.14, sehingga perolehan data tersebut dapat disimpulkan bahwa nilai F hitung sebesar 29,068 > 3,14 dan nilai sigi 0,000 $<0,05$ sehingga dapat dikatakan bahwa pengetahuan dan motivasi mahasiswa program studi perbankan syariah berpengaruh positif dan signifikan secara bersama-sama terhadap minat berinvestasi saham di pasar modal syariah.

Uji t

Uji t yang dilakukan bertujuan untuk mengetahui pengaruh secara masing-masing atau satu variabel independen terhadap variabel dependen, berikut hasil uji t yang didapat, diantaranya:

Tabel 8 Hasil Uji $t$

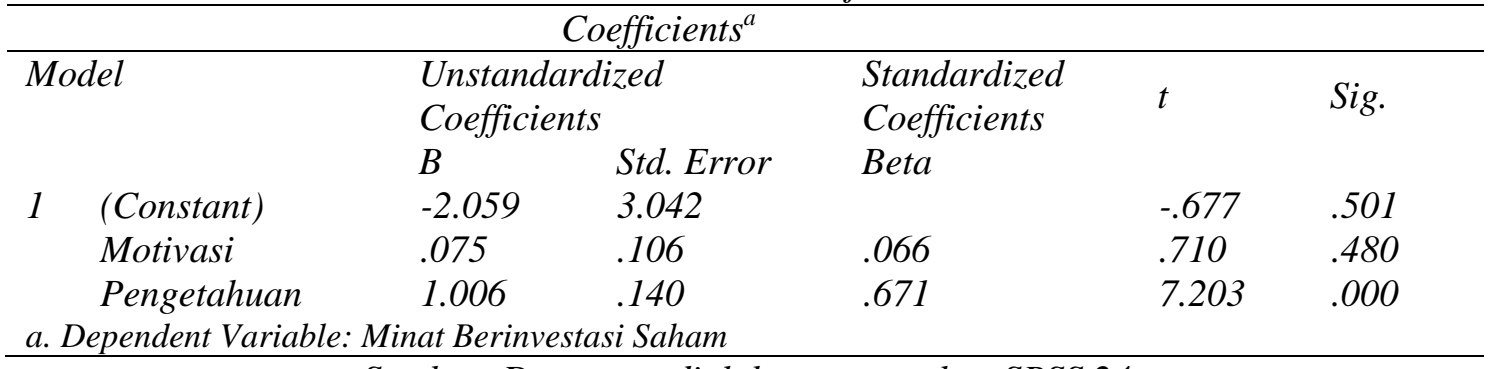

Sumber: Data yang diolah menggunakan SPSS 24

Berdasarkan pada tabel di atas, maka diperoleh model persamaan regresi diantaranya sebagai berikut:

$$
\begin{aligned}
& Y=a+b_{1} x_{1}+b_{2} x_{2} \\
& Y=-2,059+0,075 x_{1}+1,006 x_{2}
\end{aligned}
$$

Dari hasil perhitungan pada variabel motivasi terhadap minat berinvestasi saham, maka diperoleh nilai $\mathrm{t}_{\text {hitung }}$ sebesar positif $0,710<\mathrm{t}_{\text {tabel }} 1,997$ dengan perolehan nilai sigi 0,480 > 0,05 dengan hasil tersebut, dapat disimpulkan bahwa secara parsial motivasi mahasiswa program studi perbankan syariah berpengaruh positif dan tidak signifikan terhadap variabel minat berinvestasi saham.

Pada variabel pengetahuan terhadap minat berinvestasi saham, maka diperoleh nilai thitung sebesar positif 7,203 $>t_{\text {tabel }} 1,997$ dengan perolehan nilai sigi $0,000<0,05$ dengan hasil tersebut, dapat disimpulkan bahwa secara parsial pengetahuan mahasiswa 
program studi perbankan syariah berpengaruh positif dan signifikan terhadap minat berinvestasi saham.

\section{KESIMPULAN}

Berdasarkan hasil analisis data dan pembahasan yang telah diuraikan maka dapat disimpulkan bahwa data yang dipergunakan dalam penelitian ini terdistribusi normal, tidak terdapat multikolinieritas, tidak terdapat heteroskedastisitas, dan bebas dari auto korelasi. asil uji koefisien determinasi $\left(\mathrm{R}^{2}\right)$ sebesar 0,46 berarti pengaruh variabel bebas motivasi dan pengetahuan sebesar 46,0\%, sedangkan sisanya 54,0\% dipengaruhi oleh variabel-variabel lain. Hasil uji t menunjukan motivasi mahasiswa program studi perbankan syariah, memperoleh nilai $t_{\text {hitung }}$ sebesar positif $0,710<\mathrm{t}_{\text {tabel }} 1,997$ dengan nilai sigi 0,480 > 0,05 dan pada pengetahuan mahasiswa program studi perbankan syariah, diperoleh nilai $t_{\text {hitung }}$ sebesar positif 7,203 $>t_{\text {tabel }} 1,997$ dengan nilai sigi $0,000<0,05$. Sehingga, dapat disimpulkan motivasi mahasiswa program studi perbankan syariah berpengaruh positif dan tidak signifikan terhadap minat berinvestasi saham dan pada pengetahuan mahasiswa program studi perbankan syariah berpengaruh positif dan signifikan terhadap minat berinvestasi saham. Pada hasil dari Uji F menunjukan nilai

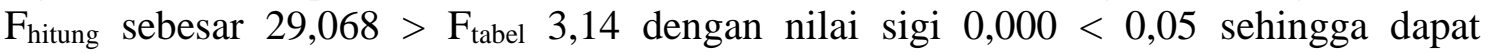
disimpulkan bahwa pengetahuan dan motivasi mahasiswa program studi perbankan syariah berpengaruh positif dan signifikan secara bersama-sama terhadap minat berinvestasi saham di pasar modal syariah.

\section{REFERENSI}

Abdalloh, Irwan. 2018. Pasar Modal Syariah. PT Elex Media Komputindo, Jakarta

Ariawaty N, Rina dan Evita N, Siti. 2018. Metode Kuntitatif Praktis. PT. Bima Pratama Sejahtera, Bandung.

Auliya F, Zakky. 2019. Investasi Saham Itu Simple. Gerbang Media, Yogyakarta.

Cahya T, Bayu dan Kusuma, Ayu. Nila. Pengaruh Motivasi dan Kemajuan Teknologi Terhadap Minat Investasi Saham. Al-Masharif: Jurnal Ilmu Ekonomi dan Keislaman, No 2, Juli-Desember 2019, Page. 198.

Darmawan, Akhmad. 2019. Pengetahuan Investasi, Motivasi Investasi, Literasi Keuangan Dan Lingkungan Keluarga Pengaruhnya Terhadap Minat Investasi Di Pasar Modal. Jurnal Ilmiah Akuntansi dan Keuangan, No. 02, 2019, Page. 46.

Huda, Nurul dan Nasution, Edwin M. 2014. Investasi Pada Pasar Modal Syariah. Kencana Prenadamedia Group, Jakarta.

Indarti, Nurul. 2014. Manajemen Pengetahuan: Teori dan Praktik, Gadjah Mada University Press, Yogyakarta.

KSEI. 2019. Laporan Kinerja Direksi 2016-2019. PT Kustodian Sentral Efek Indonesia, Jakarta.

Malik D, Ahmad. 2017. Analisis Faktor-Faktor yang Mempengaruhi Minat Masyarakat Berinvestasi di Pasar Modal Syariah Melalui Bursa Galeri Investasi UISI. Jurnal Ekonomi dan Bisnis Islam, No. 1, Januari-Juni, Page. 62.

Maunah, Binti. 2014. Psikologi Pendidikan. IAIN Tulungagung, Yoygakarta 
Mulyana, Mumuh. 2019.Mengukur Pengetahuan Investasi Para Mahasiswa Untuk Pengembangan Galeri Investasi Perguruan Tinggi. Jurnal Analisis Sistem Pendidikan Tinggi, No. 1, 2019, Page. 33

Mumpuni, Melvin dan Darmawan, Harris. 2017. Panduan Berinvestasi Saham untuk Pemula. PT. Solusi Finansialku Indonesia.

Neolaka, Amos. 2016. Metode Penelitian dan Statistika. PT Remaja Rosdakarya, Bandung.

Nandar, Haris. 2018. Faktor yang Mempengaruhi Minat Mahasiswa Berinvestasi di Pasar Modal Syariah Melalui Galeri Investasi Iain Zawiyah Cot Kala Langsa. Jurnal Kitabah, No. 2, Juli - Desember 2018, Page. 188.

Pajar C, Rizki. 2017. Pengaruh Motivasi Investasi Dan Pengetahuan Investasi Terhadap Minat Investasi Di Pasar Modal Pada Mahasiswa FE UNY. Jurnal Profita Edisi 1, Page. 1.

Priansa J, Donni. 2017. Perilaku Konsumen Dalam persaingan bisnis kontemporer. Alfabeta, Bandung.

Said, Muhammad. 2019. Hukum Bisnis Islami. Salemba Diniyah, Pamulang.

Sarwono, Jonathan. 2012. Metode Riset Skrispsi: Pendekatan Kuantitatif (Menggunakan Prosedur SPSS). PT Elex Media Komputindo, Jakarta.

Situmorang, Masri. 2014. Pengaruh Motivasi Terhadap Minat Berinvestasi di Pasar Modal Dengan Pemahaman Investasi Dan Usia Sebagai Variabel Moderat. Jurnal Jom Fekon, No. 2 Oktober 2014, Page. 4.

Siyoto, Sandu dan Sodik, A. 2015. Dasar Metodologi Penelitian. Literasi Media Publishing, Yogyakarta.

Syahrum dan Salim. 2014. Metodologi Penelitian Kuantitatif. Citrapustaka Media, Bandung.

Umar, Husein. 2014. Metode Penelitian untuk Skripsi dan Tesis Bisnis. Rajawali Pres, Jakarta. 